Article

\title{
Dazzling Displays and Hidden Departures: Bodhisattva Pedagogy as Performance in the Biographies of Two Twentieth Century Tibetan Buddhist Masters
}

\author{
Annabella Pitkin \\ College of Arts and Sciences, Lehigh University, Bethlehem, PA 18015, USA; anp515@lehigh.edu
}

Received: 11 August 2017; Accepted: 23 August 2017; Published: 30 August 2017

\begin{abstract}
This article, part of a special issue on pedagogy and performance in Tibetan Buddhism, explores two closely-related yet apparently opposite Tibetan repertoires of virtuoso Buddhist mastery as sites of performative pedagogy. One of these modes of Buddhist mastery is connected with the ideal virtuoso figure of the yogic siddha, or druptop (Tib. grub thob), and with remarkable manifestations of yogic prowess (what are sometimes called yogic "miracles" in English). The other mode is connected with the ideal of renunciation, and the Tibetan Buddhist virtuoso figure of the renunciant hermit-wanderer, or chatralwa (Tib. bya bral ba). In Indic and Tibetan literature, both of these repertoires of Buddhist mastery are classically associated with a bodhisattva's teaching activity in the world, and with a bodhisattva's use of many kinds of skillful means (Skt. upāya; Tib. thabs) to develop individuals on the Buddhist path. (A bodhisattva, in Mahayana Buddhist terms, is someone who has vowed to achieve Buddhahood to benefit others.) I explore how these related modes of virtuoso pedagogical performance emerge in oral and textual life stories of two notable twentieth-century Tibetan masters. These modes of virtuoso Buddhist pedagogy and Tibetan ways of talking about them challenge our understandings of what it means to "perform" and what it means to "renounce," with renunciation emerging as a guarantor of the genuineness of someone's altruism.
\end{abstract}

Keywords: Tibetan Buddhism; pedagogy; performance; renunciation; yogic power; bodhisattva; 20th century

\section{Prelude}

Scene One:

The year is 1956. A man is leaving a teaching job in secret, to resume a life of anonymity, intentional poverty, and wandering. The setting is Srinigar, in what is now the Indian state of Jammu-Kashmir, near the lake famous for its beauty. Khunu Lama Tenzin Gyaltsen is tall, thin, bearded, wearing thick glasses, nearing sixty. Just a few years after this scene, he will become famous as a teacher of Buddhism, Sanskrit and Tibetan literature to the Fourteenth Dalai Lama, among many others. But at this time, he is little known, a humble figure, wearing threadbare red wool robes that are too short for him. Khunu Lama has been invited to Srinigar to teach Sanskrit to the Nineteenth Kushok Bakula Rinpoche (1917-2003), a leading Buddhist reincarnate lama from Ladakh and a prominent figure in midcentury Himalayan politics. Bakula Rinpoche is so busy with governmental duties as the new Minister of Jammu-Kashmir that he almost never has time for his sessions with Khunu Lama. Instead, a young Ladakhi civil servant, Tashi Rabgias (b. 1927), an aspiring poet and scholar himself, becomes the beneficiary of Khunu Lama's learning. Fifty years later, when I meet him in 2004, Tashi Rabgias says of Khunu Lama, "It becomes a very rare chance in one's life, to see such a great teacher." 
But the renunciant Khunu Lama is restless in the lovely bungalow by the lake, with the minister who never has time to study, and he decides to leave, with no notice or fanfare. The young Tashi Rabgias is most upset. This is a startling breach of protocol that he dreads having to explain to Minister Bakula. And personally, he does not want to lose his teacher. He pleads with Khunu Lama to stay. Finally in despair, Tashi Rabgias blurts out to Khunu Lama, "Sir, if you do like this it will be ... just like escaping, just like running away." He recalls being horrified at his own rudeness. But in his recollection, Khunu Lama simply nods, and says, "Yes. Yes, it is like this. I have always been escaping."1

\section{Scene Two:}

It is the mid 1930s. Two men meet in a meditation cave on a steep mountainside in Central Tibet, and make a deep impression on one another. The meditation cave is located above Drikung Til, the main monastery of the Drikung Kagyü tradition of Tibetan Buddhism. It is the long-time residence of Drikung Amgön Rinpoche, an early twentieth century yogic master still venerated today by Drikung Kagyü practitioners in Tibet and the Himalayan region. Amgön Rinpoche wears his hair in long dreadlocks, marking his special status as a tantric yogin. He wears threadbare robes, similar, but not identical, to those of a monk. He is already famous for his unconventionality. This has led some of his neighbors at the monastery to try to throw him out, accusing him of being crazy. He is much beloved by the monastery's leader, who defends him with the words, "If you expel him, then I too will leave." 2

One day, he receives a visitor whose origins lie far away, on the other side of the Himalayas, in what is now India. His visitor is the same Khunu Lama Tenzin Gyaltsen we have just met, but in this scene Khunu Lama is some twenty years younger, though already following a lifestyle of intentional wandering, and beginning to be known for his scholarship and Buddhist practice. When they meet, Amgön Rinpoche impresses Khunu Lama, first by pushing back the rock walls of his cave with his hand to make a bigger space, and then by serving Khunu Lama tea and molasses sugar that are inexhaustible, never running out. Here is the account of their meeting from the most recent Tibetan religious biography of Amgön Rinpoche:

As it happened that when the famous Kinnauri scholar-adept, the great Tenzin Gyaltsen [Khunu Lama], came to Central Tibet from Kham, he went to Drikung for pilgrimage and to meet Amgön Rinpoche. The door of Amgön Rinpoche's place was so tiny that only he himself could fit inside, so Amgön Rinpoche widened it, by pushing back the rock. After which, then saying, "Oh, my dear Dharma brother has arrived!” Amgön Rinpoche delightedly invited Khunu Rinpoche inside. Offering tea from a tiny little teapot, Amgön Rinpoche kept pouring tea that never ran out. And Amgön Rinpoche gave Khunu Lama a lump of molasses sugar, which was also inexhaustible. So, by these methods, Amgön Rinpoche having totally enraptured his mind, Khunu Lama said, "The appearance of a great mahasiddha [great yogic master] like this even in this degenerate time is greatly amazing" and praised him again and again. (Dkon mchog rgya mtsho Ra se zla ba, pp. 57-58)

\section{Introduction}

Buddhist philosophers and meditators in many historical periods and cultural settings have used vocabularies of illusion, costume, display, and magic show-all terms intimately connected to notions of performance-as languages for communicating Buddhist insights about the nature of reality and

1 Tashi Rabgias, interview 2004, Leh, Ladakh (see Appendix A); interview in English. Tashi Rabgias is one of Ladakh's senior literary eminences. Also working for Bakula Rinpoche at that time was K. Angrup, a young scholar from Lahaul, India who also became Khunu Lama's student and later his main Tibetan-language biographer.

2 Dordzin Rinpoche, interview, Dehradun, India, 2013, interview in Tibetan (all translations from Tibetan here and following are my own unless otherwise indicated.) 
the dangers of delusion. Buddhist thinkers use such vocabularies of performance both to evoke the misleading quality of ordinary perceptions of self and phenomena, and to teach their transcendence. ${ }^{3}$

This article, part of a special issue of Religions on pedagogy and performance in Tibetan Buddhism, draws on the category of performance as an analytic lens for reflecting on Buddhist modes of exercising or transmitting mastery on the Buddhist path. In this article, I examine performative pedagogies and pedagogical performances attributed to two notable twentieth century Tibetan Buddhist masters, Drikung Drubwang Amgön Könchok Lodrö Rinpoche ('Bri gung grub dbang a mgon dkon mchog blo gros rin po che, late nineteenth century to 1945, hereafter referred to as Amgön Rinpoche), and Khunu Lama Tenzin Gyaltsen (Khu nu bla ma bstan 'dzin rgyal mtshan, 1895-1977). I ask how each man's distinctive style of Buddhist virtuosity raises questions about what "performance" might mean in the context of Buddhist teaching. In particular, I explore the interplay between those aspects of Amgön's and Khunu Lama's activities that Tibetan narrators and commentators frame as natural or spontaneous, and those they frame as intentional.

Drikung Amgön Rinpoche was an important early twentieth century Tibetan yogic practitioner in the Drikung Kagyü lineage of Tibetan Buddhism. He lived most of his life in retreat, in a cave hermitage on the mountainside above the main Drikung Kagyü monastery of Drikung Til in Central Tibet, about 150 kilometers outside Lhasa. ${ }^{4}$ Obscure in his early years, he eventually came to be quite widely known, revered by prominent Lhasa aristocrats and by ordinary people in the Drikung region, even drawing students from as far away as Eastern Tibet, at that time a journey of weeks or months away. Most famously, following the death of the Thirteenth Dalai Lama in 1933, the powerful and often controversial Regent of Tibet, Reting Rinpoche Thubten Jampel Yeshe Gyaltsen (Rwa sgreng rin po che thub bstan 'jam dpal ye shes rgyal mtshan, 1911-1947) sought out Amgön Rinpoche to request his help in locating the child who would be recognized as the Fourteenth Dalai Lama. In 2004, a leading present-day Drikung intellectual, Khenpo Könchok Gyatso (Mkhan po dkon mchog rgya mtsho, b. 1969, who also writes under the pen name Ra se zla ba or Ra se dkon mchog rgya mtsho), published a substantial religious biography or namtar (Tib. rnam thar) of Amgön Rinpoche. This publication gives a sense of Amgön's ongoing relevance and interest for contemporary Drikung Kagyü community members, who recall him as a great yogic master of the pre-1959 period (Dkon mchog rgya mtsho Ra se zla ba). 5,6

Khunu Lama, on the other hand, was from the outskirts of geographic Tibet, from the Indo-Tibetan border region called Kinnaur (Tib. Khu nu) which is now within the present-day Indian state of Himachal Pradesh. Although Khunu Lama had some connections to the Drikung Kagyü lineage,

3 Although space does not permit full consideration here, we might note that Buddhist philosophers from a range of Buddhist traditions understand identity and selfhood as processual, impermanent, and socially constituted, in ways that resonate with moves by European and American thinkers like Judith Butler to understand identity as performative (Butler 1988).

4 The Kagyü school is one of the four main branches of Tibetan Buddhism active today. The Drikung Kagyü is one of the leading Kagyü lineages surviving into the present. Drikung Til Monastery ('Bri gung mthil dgon pa) was founded in Central Tibet in 1179 by Kyobpa Jigten Sumgön (Skyob pa 'jig rten gsum mgon, 1143-217), the progenitor of the Drikung tradition (Gruber 2010; Dkon mchog rgya mtsho Ra se zla ba). Relatedly see (Kapstein 1998).

5 Elite scholars and meditators and older people from the Drikung region tend to be those most familiar with Amgön Rinpoche's life. For an overview of the issues involved in translating the Tibetan term rnam thar, see for instance (Jacoby 2014; Quintman 2013; Gyatso 1998; Willis 1995).

6 The 2004 biography is based in part on a previous 1996 biography ('Bri gung pa chos ‘byor 1996). The 2004 biography incorporates an exceptional number of oral interviews collected by Könchok Gyatso and others, and is one of my main sources for discussing Amgön Rinpoche's life here. I supplement textual sources with oral accounts shared with me by leading Drikung scholars at the Drikung Kagyü Institute in Dehradun, India and in New York City, between 2013-2016. The Drikung scholar-practitioners whose incisive interpretations I engage with here are: the senior yogic retreat master Dordzin Drupön Döndrup Palden Rinpoche (Rdor 'dzin sgrub dpon don grub dpal ldan rin po che; hereafter Dordzin Rinpoche); Khenchen Nyima Gyaltsen (Mkhan chen nyi ma rgyal mtshan, b. 1976), a principle of the Kagyu Monastic College in Dehradun, India; and Karma Rinchen (Karma rin chen, b. 1980), a lay scholar-practitioner educated in classic Drikung monastic and yogic curricula, who currently lives in New York City. These three thinkers are elite scholar-practitioners; for reasons of length I do not explore perspectives of other kinds of audiences here. For a valuable alternative methodology, see (Sihlé 2013, pp. 215-21). For further discussion of Amgön Rinpoche's activities and themes related to those explored here, see (Pitkin 2016). A brief but relevant discussion of Amgön also appears in (DiValerio 2015, pp. 226-27). 
he was famously ecumenical in his religious affiliations, seeking out relationships with Buddhist teachers from a wide range of lineages and schools, including Nyingma, Drukpa Kagyü, Sakya, and Geluk, among others. ${ }^{7}$ Khunu Lama left his birthplace in Kinnaur as a young man, and traveled widely during the first half of his adult life in Sikkim, Central Tibet and Eastern Tibet, from 1914 through the 1930s. During this time, he met Amgön Rinpoche. By the early 1940s, Khunu Lama had left Tibet and returned to India, where he lived for the remainder of his life, until his death in 1977. ${ }^{8}$

Like Amgön Rinpoche, Khunu Lama also was little known in his early life. He gradually became more famous, both as a teacher to Himalayan people (especially in his home region of Kinnaur) and also among Tibetans, who began to arrive in India as refugees in the years after 1959, when the newly-established People's Republic of China consolidated its takeover of Tibet. Through his teaching activities, Khunu Lama played a role in maintaining the continuity of Tibetan Buddhism in exile after 1959. Eventually, Khunu Lama became a teacher of the Fourteenth Dalai Lama, which brought Khunu Lama to much wider attention. Many Tibetan Buddhist teachers who are prominent today studied with Khunu Lama in India or Nepal, as did several of the first groups of westerners to ordain in the Tibetan Buddhist tradition. The Dalai Lama continues to mention Khunu Lama in public teachings and publications, so that Khunu Lama, like Amgön Rinpoche, is remembered as a great master of the recent past. ${ }^{9}$

During the course of ten years of research on Khunu Lama's life (2004-2014), and four years of research on Amgön Rinpoche (2012-2016), I met with Tibetan monastic scholars, former students of both men, and Buddhist practitioners from communities connected with them. These experts shared and analyzed textual and oral narratives about them with me. Throughout our conversations, these scholars and practitioners highlighted ways in which both men are remembered as bodhisattvas. (A bodhisattva, in Mahayana Buddhist terms, is someone who has vowed to actualize the Buddhist path for the sake of others, in order to bring all beings to Buddhahood; such a person represents the ideal Mahayana practitioner.) By understanding Amgön Rinpoche and Khunu Lama as compassionate and powerful bodhisattvas, people in communities that remember them articulate an interpretive framework in which even their most surprising actions become legible and meaningful, following a common pattern in Tibetan accounts of life stories of Buddhist masters. (For instance (Gyatso 1998; Quintman 2013; Patrul Rinpoche/Padmakara Translation Group 1994; Shantideva 1997)). I argue that by using performance as a lens to explore differences and complementarities in stories about these two individuals, we can enrich our thinking about the figure of the bodhisattva in Tibetan Buddhist narratives more generally. In particular, I suggest that the category of performance brings into view subtle narrative tensions surrounding the forms of power that bodhisattva figures may exercise.

\section{Pedagogies of Absence and Presence}

The vignettes with which this essay began highlight differences in how these two figures are remembered. The opening anecdote, my paraphrase of the oral account told to me in 2004 by Tashi Rabgias, describes a man quietly slipping away from a teaching job, hardly most people's conventional notion of "performance." Khunu Lama is introduced as a famous teacher of Buddhism and Sanskrit. But Tashi Rabgias does not focus on his teaching; rather, he focuses on Khunu Lama's departure, his "escape." He emphasizes that Khunu Lama is "always" leaving, that he leaves without warning,

7 On issues related to whether the Tibetan term for "non-sectarian," ri mé (ris med) is appropriate for Khunu Lama see (Gardner 2006; Pitkin 2009, 2011).

8 My main sources for Khunu Lama's life here are my own interviews with Khunu Lama's surviving students, primarily done between 2004-2014, and Tibetan textual accounts by three of his former students, K. Angrup (Angrup 1989, 2005), Khetsun Sangpo Rinpoche (Khetsun Sangpo n.d.), and Drikung Lamchen Gyalpo Rinpoche (Lamchen Gyalpo 2011). Works on or connected to Khunu Lama's life in western languages include (Dodin 1997; LaMacchia 2008; Manshardt 2004, 2008; Sparham 1999). On Khunu Lama's dates and the challenges of precisely dating his activities, see (Pitkin 2009; Angrup 1989, 2005; Dodin 1997; Lamchen Gyalpo 2011; Khetsun Sangpo n.d.; Manshardt 2004; Sparham 1999).

9 For instance, (Dalai Lama 1994). 
in secret, and that his departure cannot be stopped. This scene dramatizes a key aspect of Khunu Lama's famed renunciation, namely his avoidance of honors, prominent teaching positions, salaries, and fixed places of residence. In this story, we see (or we think we see) Khunu Lama leaving a devoted student, stepping out of the limelight, away from view, against a student's protests. By framing this anecdote as a narrative of his teacher's departure, Tashi Rabgias here highlights Khunu Lama's absence.

In contrast, the second scene, in which Khunu Lama meets Amgön Rinpoche, focuses on what I will call performative presence. This quality of presence is intimately bound up with the relational and pedagogical qualities of Amgön's yogic displays. Presence here implies being with another person, potentially in multiple ways. On one level, Amgön's and Khunu Lama's physical presence together and their interaction with each other are vital to the encounter that occurs. Khunu Lama and Amgön Rinpoche see and touch one another. They meet in person, face to face. (Indeed, this quality of face-to-face presence in their interaction will appear again as central, in a second version of the story of their meeting that I discuss at the end of this essay).

When Amgön Rinpoche in this scene performs what English speakers sometimes call miracles, ${ }^{10}$ he is both revealing to Khunu Lama something about himself and his own yogic attainments, and at the same time he is also engaging with Khunu Lama as an honored fellow practitioner. Khunu Lama for his part participates with his own presence: he enters into the yogically enlarged cave, enjoys the tea and sugar, and responds to these experiences with expressions of awe, pleasure, and apparently, faith. His presence as witness and participant is necessary for Amgön Rinpoche's yogic performance to be fully realized.

Taken together, the narrative contrasts between the two brief scenes with which this article began reflect broader differences in how the activities of these two men are presented in oral and textual sources. Amgön Rinpoche's life and activities are remembered in ways that emphasize his dramatic and dazzling displays of yogic power. Textual biographies and oral accounts describe Amgön's yogic displays in great detail. Stories of these displays are perhaps the most frequently told stories about him. His most recent textual biography, from 2004, is filled with such accounts (Dkon mchog rgya mtsho Ra se zla ba). Amgön tells the future, exposes criminals through his clairvoyance, and brings hot Tibetan dumplings on foot all the way from the distant city of Lhasa to the monastery of Drikung Til in the space of an afternoon, to dazzle disbelieving young monks or other visitors (for instance, (Dkon mchog rgya mtsho Ra se zla ba, pp. 29-31)). Amgön's most famous public role, as advisor and sometime teacher of the powerful Regent Reting Rinpoche, is described in oral and textual accounts as directly hinging on Amgön's yogic powers. His clairvoyance is described as having particularly awed Reting, and as having made Amgön a vital resource for locating the newly reincarnated Fourteenth Dalai Lama.

Khunu Lama, on the other hand, has become most famous for his ascetic, "beggar" persona as a wandering chatralwa (Tib. bya bral ba) renunciant-hermit, ${ }^{11}$ and as a "hidden yogin" (Tib. sbas pa' $i$ rnal 'byor pa), a practitioner who makes no show of his or her practice or accomplishments. ${ }^{12} \mathrm{He}$ is memorialized in ways that highlight his practice of literally concealing himself through a lifestyle of constant departures and wandering, of refusing any honors that might lead to public recognition,

10 I largely avoid the term "miracle" in this article as a translation for various kinds of yogic display and displays of realization, because of the imperfect fit between the implications of the English term and the ways that Tibetan Buddhists analyze forms of yogic display. I discuss these issues in more detail in (Pitkin 2016) and briefly in what follows. The drawback of not using "miracle" is the lack of another equally broad English term to refer to the range of displays of Buddhist powers discussed in Buddhist texts. I use the terms "yogic display" and "display of realization" most frequently in what follows, and offer additional analysis of the semantic fields involved below. For in depth treatment of these and related issues in Indic materials, see (Fiordalis 2008, 2010, 2013, 2014), and (Clough 2010; Gethin 2011; Gómez 2010; Pranke 2010; Scheible 2010). Fiordalis in (Fiordalis 2010, 2014) offers important comments on modernist and rationalist contexts for critiques of the term "miracle." I discuss several of these issues further in (Pitkin 2016).

11 On the chatralwa ideal, see (Patrul Rinpoche/Padmakara Translation Group 1994; Pitkin 2009; Pitkin).

12 Chokyi Nyima Rinpoche, himself a student of Khunu Lama, specified that Khunu Lama should be understood as a "hidden yogin." Chokyi Nyima Rinpoche interview 2010. 
and of living in extremely impoverished, obscure, and often non-Tibetan surroundings. Although his students and biographers very occasionally describe him as demonstrating clairvoyance and other yogic abilities, for the most part, narratives about Khunu Lama's life rarely mention any yogic displays. Stories about him instead strongly emphasize his renunciation and "hiddenness," through a recurring vocabulary of poverty, separation and absence. In the words of Tulku Pema Wangyal, himself a student of Khunu Lama, "He had hardly anything, you know? He had what he was wearing, that's all he had, nothing else ... And whatever people offer him ... he used to leave it under his bed and the next person who comes, he gives them away ... And he used to say that 'In the past, people used to go do retreat in the mountains. These days we should not go to the mountains, because the mountain is a very touristic place.' And as he lived in Benares [Varanasi], hardly anybody knew him ... and he was very, very quiet."13 Textual biographies and oral stories about him describe him as "always escaping," in Tashi Rabgias' words, or as being literally hard for his disciples to find. These stories are often framed in poignant terms that emphasize the emotional dimensions of renunciation, discomfort, searching, and longing.

Khunu Lama and Amgön Rinpoche thus appear to be memorialized today as embodying opposite modes of Buddhist virtuosity: presence versus absence, display versus concealment, the power of yogic virtuosity versus the power of renunciation. Indeed, at first glance, it may appear that Khunu Lama in some sense avoids performing, while Amgön Rinpoche embraces it.

Yet narratives of their activities are in fact deeply complementary, particularly when viewed through the lens of performance. As I will argue, both men are virtuosic performers of both presence and absence. Khunu Lama's renunciation, foregrounding absence and concealment as it apparently does, can nevertheless be understood as a dramatic, pedagogical performance. Amgön Rinpoche's exuberant display of yogic powers, on the other hand, turns out to incorporate multiple levels of renunciatory absence.

\section{The Buddhist Pedagogies of Khunu Lama and Amgön Rinpoche: Performing Renunciation and Yogic Power}

In thinking about Khunu Lama's and Amgön Rinpoche's styles of Buddhist pedagogy, it is in fact the similarities in how they are said to have behaved that make them especially interesting to think about together. Both Khunu Lama and Amgön Rinpoche were committed to lifelong forms of Buddhist practice centered on renunciation. For each of them, this involved leaving behind lay household and family life, as well as abandoning many of the trappings of conventional Buddhist monastic "success." They are both remembered as displaying virtuosic levels of the Tibetan chatralwa ideal of hermitic renunciant practice: dressing in ragged clothes, eating the simplest food, living in caves or unfurnished rooms, declining or avoiding money, comfort, honors, and lavish donations, and eschewing most forms of fame or public attention. Both men also are remembered as disregarding social conventions, from politeness to institutional rules. They are remembered as speaking bluntly (and sometimes rudely) to all they met, no matter how powerful, and for showing a strong preference for poor and uneducated people over aristocrats and political leaders, though in fact both men eventually counted powerful people among their disciples.

The 2004 religious biography of Amgön Rinpoche, for instance, recounts a series of humorous exchanges between Amgön and Reting Rinpoche, occurring when the latter comes to request Amgön's assistance in divining the location of the newly incarnated Fourteenth Dalai Lama. Reting, whose regency was marked by conflict and controversy, ultimately fell from power and died in prison. He appears in Amgön's biography as a grand but ambiguous figure, a Buddhist hierarch who has become enmeshed in worldly power with its attendant spiritual and political risks. In several episodes in the biography, we see Amgön teasing Reting about his worldly status. In one scene, Amgön

13 Tulku Pema Wangyal interview 2005. 
comments on Reting's ostentatious retinue, remarking that the "king" of Tibet has arrived (ironic, since Reting is merely the Regent), and saying that his cave is too small for the retinue to enter (Dkon mchog rgya mtsho Ra se zla ba, p. 68.). When Reting asks what he can offer Amgön that Amgön needs or would like, Amgön replies that he will only accept "loose tea as black as ants' feet" (ja 'bu grog ma' $i$ rkang pa 'dra po nag hrug hrug de 'dra) (Dkon mchog rgya mtsho Ra se zla ba, pp. 68-69; Pitkin 2016). It's not clear what kind of tea this is, except that it sounds both funny (and fancy), and difficult to find, perhaps hinting to Reting that there are gifts he cannot bestow. Amgön presents himself as a renunciant practitioner who does not need material things, while subtly tweaking Reting, in theory also a renunciant, for his accumulation of wealth. One gets a sense both of Amgön's renunciation in practical terms (living in a tiny cave, refusing valuable gifts) and of his unconventional, humorous style of critiquing powerful people.

Khunu Lama, in an episode that has certain structural parallels to the story just told about Amgön, is himself described as initially refusing a visit from the Fourteenth Dalai Lama at his small room in Varanasi:

[His Holiness Dalai Lama] came to meet Negi Lama [Khunu Rinpoche] accompanied by his personal secretary only. At that time Negi Lama was just recovering from a serious illness and was still feeling very weak... He was also very poor and his only property was the old torn-up blanket he was wrapped in in his empty cell ... When he was informed by the private secretary who the visitor was, he objected that he wore no appropriate clothing and had no chair for His Holiness to sit on. He claimed not to be able to receive him under such conditions. As the Dalai Lama insisted on speaking with him they both remained standing and had a talk. (Dodin 1997, p. 90) $)^{14}$

Here, the powerful visitor is a much more unambiguously positive figure than Reting appears to be. In fact, Khunu Lama went on to form an extremely warm and close teaching relationship with the Dalai Lama. However, the radical impoverishment of Khunu Lama's circumstances (no suitable clothing, only a torn blanket, no chair) and the humor implied in refusing to receive an important visitor because one is too humble resonates with the humor and style of Amgön in the previous narrative.

Another similarity between the two men is the fact that although both Amgön Rinpoche and Khunu Lama spent much of their lives in and around major Tibetan Buddhist monastic institutions, neither took the vows of full monastic ordination. Instead, they were both practitioners of non-celibate tantric forms of Tibetan Buddhist practice. ${ }^{15}$ Both were also sometimes criticized or looked down upon as crazy, poor, and strange by people following a more conventional monastic or household path. They are remembered as fitting the valorized Tibetan Buddhist convention of unconventionality, acting in ways resonant with the ideal of the mad yogin or lama nyönpa (Tib. bla ma smyon pa), a style of practitioner whose seemingly unconventional behavior is an expression of his or her yogic transcendence of all conventional conceptuality. ${ }^{16}$

Turning in more detail now to Khunu Lama, textual and oral narratives about him pay particular attention to his renunciant practice. He is remembered for his intense and often unconventional modes of renunciation, such as the ways in which he often dispensed with the ordinary trappings of Tibetan

14 Dodin's important 1997 article on Khunu Lama is based on the oral recollections of Khunu Lama's Kinnauri disciple Sangngak Tenzin (Gsang sngags bstan 'dzin), who is the narrator of this story.

15 On the ngakpa (Tib. ngags pa) ideal see (Jacoby 2014; Jacoby and Terrone 2009). Several people described Amgön Rinpoche as a ngakpa when explaining his style of practice (Dordzin Rinpoche interview 2013; Karma Rinchen interview 2014). Khunu Lama's case is more complex, since students from different points in his life perceived him differently. Several former students report that Khunu Lama himself said he never took full monastic ordination, although he did take novice vows; some students report that this was specifically in order to practice tantra (Pitkin 2009).

16 On the lama nyönpa ideal see (Ardussi and Epstein 1975; DiValerio 2015; Quintman 2013; Larsson 2012; Stearns 2007). The "mad yogin" or "crazy lama" is closely connected to the chatralwa beggar-hermit ideal type. Chatralwa-style renunciation of fame and social rewards can often be linked to dramatically unconventional behavior as I discuss in (Pitkin 2009; Pitkin). I consider the significance of these ideal types for Khunu Lama's and Amgön Rinpoche's styles of performance further below. 
Buddhism, his unusual dress, his disengagement from Tibetan Buddhist ritual, and his frequent choice of non-Tibetan or non-Buddhist companions. His renunciation is presented as virtuosic in multiple senses of that term, with a dramatic quality that lends itself to storytelling.

I have already noted his frequent, at times nearly constant travel. Wandering is an important dimension of his renunciation, a literal abandonment of home or fixed abode. It is also an important aspect of his hiddenness, making him hard to find and distancing him from positions of renown or worldly "success." Khunu Lama also practiced other forms of renunciation, including radically limiting his own material possessions, and in the latter part of his life in India, choosing dwelling places that were often located in non-Tibetan or Himalayan and non-Buddhist social spaces. ${ }^{17}$

Perhaps the most striking example of these aspects of his renunciation is his ascetic lifestyle in an unfurnished single room in Varanasi, in a Hindu ashram called Tekra Math. This room, in a highly unusual location for a Tibetan Buddhist master, was his home for many years in India during the second half of his life, at times when he was not traveling. It is the location in which the above encounter with the Dalai Lama took place. Khunu Lama was hosted at Tekra Math because one of the ashram's leaders was his former Sanskrit classmate, who had become a close friend. All the disciples who met Khunu Lama there mention the extraordinary circumstances and discomfort of this place, and the radical minimalism with which Khunu Lama lived there (Angrup 1989, 2005; Dodin 1997; Manshardt 2004; Pitkin 2009).

Stories of Khunu Lama's ascetic existence in Varanasi support the interpretation, offered by many former students, that his residence there served as an intentional, quasi yogic exercise. ${ }^{18}$ Khunu Lama's student and main Tibetan-language biographer K. Angrup, for instance, recalled Khunu Lama's room at Tekra Math as unbearably hot for much of the year, and full of mosquitoes, because the windows and door had no glass. The lack of glass also meant that during the rains, water would collect on the floor of the room. The space lacked even basic furnishings like chairs, and had no running water or toilet facility. Angrup described how Khunu Lama would go downstairs and out to a pump in the street to get water in his cupped hands when he needed a drink. According to Angrup, he asked Khunu Lama why the latter did not get a pitcher and a cup to keep in his room. Angrup said that Khunu Lama replied, "First you get one cup and a pitcher. Then you need another cup in case you have a visitor. Then you need a third cup in case someone else comes. And that's how possessions accumulate." 19

Khunu Lama was likewise said to dress in unusual, socially ambiguous and (for some Tibetans) low-status ways that made him hard to identify as a Tibetan Buddhist teacher or scholar. Sometimes Khunu Lama is described as wearing a long, ragged red wool Himalayan layman's robe, looking "like a beggar" in the words of several former students. ${ }^{20}$ Elsewhere he is described as wearing the yellow clothes of a sadhu, a Hindu renunciant, an unusual choice for a Tibetan Buddhist master. Khunu Lama is described by his students as walking in the evenings by the Ganges in Varanasi, debating philosophy with Hindu and Jain scholars and renunciants (another unconventional activity). In his sadhu robes, he is described as blending in with the other Indian renunciants by the river (Angrup 1989, 2005; Dodin 1997; Lamchen Gyalpo 2011; Pitkin 2009; Pitkin; Sparham 1999). ${ }^{21}$

Whether Indic or Tibetan in style, his clothing emerges in stories as an expression both of his practice of disengagement from possessions, and his renunciation of fame and social status. His ragged and often low-status clothing (beggar-like, not recognizably Tibetan, not recognizably monastic) often

17 An important dimension of Khunu Lama's willingness to live in non-Tibetan and non-Buddhist spaces in India was his own identity as a Kinnauri, a person from a region on the Himalayan border between Tibet and India, culturally distinct from both. Space limits discussion of this dynamic here; but see (Pitkin 2009, 2011).

18 K. Angrup interview 2004; Geshe Yeshe Tapgyes, interview 2004; Trulku Pema Wangyal interview 2005; Chokyi Nyima Rinpoche interview 2010. (Dodin 1997; Lamchen Gyalpo 2011; Pitkin 2009; Pitkin).

19 K. Angrup interview 2004; Angrup spoke in English.

20 Trulku Pema Wangyal interview 2005; Sem Trinley Ongmo interview 2004.

21 K. Angrup interview 2004. 
seems to have served as another form of concealment, making him hard to identify as a great Tibetan Buddhist practitioner. ${ }^{22}$ Because of this, there are many stories from his later years in India in the 1960s and 1970s of his being ignored or looked down upon initially, and his qualities as a great teacher not being recognized by people in the Tibetan community. Often a turning point in such stories is when people witnessed the Dalai Lama's reverence for him. Oral narratives describe how when individuals or groups of people saw the Dalai Lama prostrate to Khunu Lama and greet him with devotion, then, in the words of one former student, "People began to line up for three hours to see him." ${ }^{23}$

Across these various accounts, one gets a visual impression of mingled concealment and an almost performative disguise. Khunu Lama makes his special qualities as a Buddhist master hard to see, just as he seems to have often literally made himself hard for disciples to find. Yet this ironically makes him stand out vividly in our mental image of him, as he does in students' recollections. Khunu Lama's practice of renunciation (his unusual clothes and companions, his bare, hot mosquito-infested room, without even a cup to drink from) emerges as almost flamboyant in these narratives, indeed as a kind of performance. We encounter a drama of concealment, a visible display of simplicity.

To point this out is by no means to suggest that Khunu Lama's practice of renunciation was not sincere or factual (i.e., that it was "just an act" or "just a story," although these questions themselves require the vocabulary of performance in an interesting way). Rather, by bringing the lens of performance to bear on how Khunu Lama's activities are remembered, we can see his renunciation as a social and pedagogical act, as well as a personal and inward one. When seen as a kind of performance, aimed in some sense at others as well as at himself, renunciation appears explicitly as an aspect of his teaching, an interpersonal form of performative pedagogy, contra the popular western interpretation that renunciation involves leaving sociability behind. ${ }^{24}$

At the same time, Khunu Lama's practice of self-concealment and frequent departure highlights the potential challenges such renunciatory pedagogy can pose for students: students long for him, miss him, search for him, but he is often difficult to find. Khunu Lama's performative pedagogy of renunciation thus has a double edge: he models for students what a practice of renunciation (in Tibetan accounts the essential bedrock of the Buddhist path) can look like. But at the same time, this performance of renunciation risks making Khunu Lama invisible and unfindable, and thus unavailable to students.

Amgön Rinpoche, for his part, was also an austere renunciant, living in a style very close to Khunu Lama's. Amgön is described as also avoiding honors and donations (as when he humorously rejects the lavish donations Reting Rinpoche tries to offer), and as eating the most minimal food, wearing threadbare clothes, sometimes even appearing mad in his disregard for convention. He spent most of his life in retreat in a mountain cave, near the main bustle of Drikung Til monastery, but slightly removed from it. He did not conceal himself by traveling or living in unusual places like Khunu Lama. Rather, he concealed himself by remaining still, hidden in retreat. While his oral and textual biographies are filled with vivid stories of his startling, dramatic displays of yogic power, he nevertheless is presented throughout the narratives as someone who avoided fame and attention for their own sake. A number of his yogic displays occurred where only a few people (sometimes even just one person) could witness them, such as when he delighted Khunu Lama with the inexhaustible tea and sugar. There are stories about him sometimes swearing witnesses to secrecy, although at other times his yogic power is described as manifesting in highly public ways, such as in his clairvoyant interactions with Reting and his retinue, or in the much-loved stories of him bringing fresh, hot momos

22 Drukpa Trulku interview 2006, interviewed by David Jackson. Interview shared by David Jackson, personal communication.

23 Among others, Mrs. Namgyel Taklha interview 2004; Rakra Rinpoche interview 2006; Khenpo Sonam Topgyal interview 2006 (the source of the quote).

24 On the complex rhetorics of renunciation and the many contexts of sociality in which Buddhists have practiced it, see for instance (Schopen 1997; Clarke 2013); also (Mills 2000). 
( $m o g$ mog, Tibetan dumplings) from Lhasa to Drikung, making the long journey in a mere few hours (Dkon mchog rgya mtsho Ra se zla ba, pp. 68-71). ${ }^{25}$

One of Amgön's most dazzling displays of yogic power highlights his seclusion, concealment, and rejection of fame, while also flagging the performative drama of his yogic activity. While in retreat in his cave, one day Amgön Rinpoche is said to have astonished the disciple who acted as his retreat attendant by saying that he would go on pilgrimage the following day to the sacred mountain of Tsari, (one of the major mountain pilgrimages in the Tibetan Buddhist world and a long journey from Drikung Til). The disciple was startled, given the great distance involved and the fact that Amgön did not seem to be making any preparations to leave the cave where he was in retreat. When the disciple brought Amgön water and supplies a day later, there above the door of the meditation cave was a fresh, green bamboo shoot. Amgön explained that he had just brought it back from Tsari after doing the pilgrimage, and had planted it. (The Drikung retreat master Dordzin Rinpoche who told me this narrative in 2013 mentioned that people said the plant remained growing there until very recently). Amgön is described as having sworn the amazed and awed disciple to secrecy, saying, "Don't tell anyone this until after I'm dead." Oral and textual accounts say that people from Drikung who were already on the Tsari pilgrimage that day (having gone there in the ordinary way), reported seeing Amgön on various parts of the mountain while they were walking. ${ }^{26}$

In this episode, which appears in both textual and oral sources, audiences encounter the extraordinary extent of Amgön's yogic capacities in a context that is both extremely private, and yet also involves a kind of going out into the world. Amgön Rinpoche is secluded in retreat in his cave hermitage. One might expect narratives focused on his absence and withdrawal to emerge, similar to those about Khunu Lama. But instead, in this episode Amgön journeys yogically far outside the cave. He is seen by others on the mountain. He brings back the living bamboo shoot as dazzling proof of his journey for his disciple (and perhaps others) at Drikung Til.

This would seem to be a dramatic performance of yogic power, a bursting of the conventional parameters of his renunciant seclusion and a display of his extraordinary capacities. To travel all the way to Tsari in one night, to complete one of the arduous mountain circumambulation routes, and to return the next day with plants from Tsari that do not normally grow in the Drikung region suggests that Amgön has mastered the remarkable yogic accomplishments of rapid locomotion and "making what is near far and far near." (Gethin 2011) Yet in the story, Amgön swears his disciple to secrecy during Amgön's own lifetime. This seems to return this dramatic yogic performance of outwardness and presence to the realm of the hidden and secluded.

I suggest that the moment in the story where Amgön swears his disciple to secrecy is significant, (and forms part of a narrative pattern that occurs in other accounts of Tibetan masters as well). ${ }^{27}$ Swearing his disciple to secrecy allows Amgön to perform an extraordinary yogic act (one which marks the high level of his meditative attainment), while also maintaining a certain distance from that act, both in his interactions with this particular disciple, and within the structure of the narrative. That is to say, by acting in such a way as to limit the public awareness of his remarkable feat, Amgön renounces the fame and attention that such a feat would normally bring. One could say in Buddhist terms that this story shows him giving up the ego satisfactions and attachments of being publicly known as a powerful yogin. The story of his trip to Tsari now circulates widely, and forms part of Amgön's posthumous identity as a great yogic master. Yet Amgön's dual role in the story, as both the enacter of an extraordinary yogic deed and as the concealer of it, narratively signals to audiences his non-egocentric, and therefore in Buddhist terms, his moral relationship to the drama and performativity

25 Also note discussion in (DiValerio 2015, pp. 226-27).

26 Dordzin Rinpoche interview 2013; this episode is also recounted, with slight differences of emphasis, in (Dkon mchog rgya mtsho Ra se zla ba, pp. 51-52).

27 See for instance (Stearns 2007); see also relatedly (Fiordalis 2008, 2010, 2013, 2014; Gethin 2011; Gómez 2010) on issues of concealment and display of Buddhist powers in earlier Pali and Sanskrit sources. 
of his own yogic power. ${ }^{28}$ The combined performance and concealment of his yogic act is explained by Tibetan narrators and commentators as reflecting Amgön's liberated state (in the Buddhist sense), his authenticity, and his trustworthiness. ${ }^{29}$

The moment at which Amgön swears his disciple to secrecy may thus itself also be seen as a kind of performance - not with the pejorative implication that it is "fake," but in the sense that this display of secrecy too is a part of Amgön's pedagogy. Swearing his disciple to secrecy functions as a dramatic expression of Amgön's non-grasping and non-manipulative relationship to his own extraordinary yogic capacities. In this sense, we might say that Amgön performatively models an ideal, non-grasping attitude toward yogic power for the benefit of the disciple, and for the story's future audiences. By doing so, Amgön also reveals what Tibetan exegetes describe as the fundamentally spontaneous, rather than calculated, nature of his own remarkable deeds.

Indeed, contemporary Drikung scholars with whom I discussed narratives about Amgön and his life explicitly highlighted this spontaneous, uncontrived quality of Amgön's yogic interventions, and linked this spontaneity to Amgön's authenticity as an enlightened master. They emphasized that Amgön's activities should be understood not as intentional, planned exercises of an "ordinary" kind of yogic power, but rather as naturally-arising manifestations of his enlightened realization. (I engage here in particular with the penetrating exegetical and philosophical approaches of the three Driking scholars who also recounted many of the oral narratives of Amgön's life that I discuss. These three exegetes are the yogic retreat master Dordzin Rinpoche, Khenchen Nyima Gyaltsen, who is one of the principals of the Drikung Kagyü Monastic College in Dehradun, and the New York-based lay scholar-practitioner Karma Rinchen. $)^{30}$

These Drikung experts explained that in order to understand the Tsari episode and other accounts of Amgön's activities, an audience or reader must distinguish between various kinds of Buddhist super power, in particular between "ordinary" forms of power, and the one "extraordinary" power, which is Buddhist enlightenment. The kind of yogic power with which Tibetan audiences tend to be most familiar is called ngödrup, which might be translated as "yogic accomplishment" or "attainment" (Skt. siddhi, Tib. dngos grub). ${ }^{31}$ Tibetan exegetes, following mainstream Indic and Tibetan Buddhist treatises, explain that ngödrup abilities are produced as a predictable side effect of concentration meditation or tantric practice. Unlike the accounts of miracles in western religious contexts, the Tibetan scholars with whom I have discussed ngödrup state that ngödrup do not represent a suspension of the laws of nature or of rationality; rather, they can be analyzed in the logical terms of cause and effect, even if they are often quite startling or dramatically exciting for bystanders. ${ }^{32,33}$

Importantly, ngödrup yogic powers, extraordinary as they may seem to witnesses, are generally classified in Tibetan texts and oral exegesis as "ordinary" (Tib. thun mong) in a soteriological sense. They are a side effect of certain meditative practices, but they are not (or at least should not be for Buddhists) the point of those practices. The only non-ordinary yogic power in this sense is

28 Note the resonances with the stance of personal humility so important in many rnam thar accounts of Tibetan masters. See for instance (Gyatso 1998; Jacoby 2014).

29 Dordzin Rinpoche interview 2013; Khenchen Nyima Gyaltsen interview 2013; Karma Rinchen interview 2014.

30 See note 8 above. I discuss the complex perspectives of these three experts in greater detail in (Pitkin 2016), and offer only a brief distillation of their comments here as relevant to the themes of this article.

31 Buddhist communities and texts have categorized yogic powers and superknowledges in a range of ways that have changed over time. See (Fiordalis 2008, 2010, 2013, 2014; Gethin 2011; Pranke 2010; Gómez 2010). Space constraints limit my focus here to these specific Tibetan accounts. An important future topic would be a detailed analysis of the history of Tibetan taxonomies of yogic power in relation to Indic sources.

32 In this statement, I follow the perspective of Khenpo Kunga Sherab based on personal communication; see (Fiordalis 2010, 2014) for an important alternate perspective. See also my discussion of the connection to modernity and secularism in (Pitkin 2016).

33 The most common Tibetan taxonomy of ngödrup are the sets of eight 'mundane' (thun mong) ngödrup, which are 'mundane' in the sense of different from the supreme siddhi of Buddhahood. Dung dkar 1981:755 (Dung dkar blo bzang 'phrin las 2002), gives a standard list: eye potion, swift-feet, sword, travels to terrestrial realms, magic pills, travels to celestial realms, invisibility, essence extract. ("mig sman/rkang mgyogs/ral gri/sa 'og/ril bu/mkha' spyod/mi snang ba/bcud len"). 
Buddhahood, also called "the supreme yogic attainment" (Tib. mchog gi dngos grub). It is this supreme form of yogic power-enlightenment itself-that should be the goal of the Buddhist path.

An advanced Buddhist practitioner can, if she or he chooses, display ngödrup powers in front of others, or use them for worldly or Buddhist goals. In addition, an enlightened individual can manifest the supreme yogic power of enlightenment in displays that disciples or potential disciples can witness. This second type of display, which reveals Buddhist enlightenment, is referred to by the Drikung scholars I spoke with as "supreme miraculous power" or "supreme miraculous display" (mchog gi $r d z u$ ' $p h r u l$; hereafter $d z u n t r u ̈ l$ for short; this term in Tibetan generally translates the Sanskrit term rddhi). ${ }^{34}$ Dordzin Rinpoche, Khenchen Nyima Gyaltsen, and Karma Rinchen described dzuntrül as enlightenment simply manifesting. Thus, in the interpretation of these scholars, although Amgön Rinpoche appears to be displaying "ordinary" yogic abilities, i.e., ngödrup, he is not. Rather, he is displaying his enlightened awareness, by displaying dzuntrül.

Dordzin Rinpoche, Khenchen Nyima Gyaltsen, and Karma Rinchen all distinguished between ngödrup and dzuntrül in terms of intentionality and spontaneity. In their analyses, ngödrup, in the sense of intentional displays or deployments of "ordinary" yogic abilities, run the risk of manipulation. Ordinary ngödrup and related kinds of powers deriving from Buddhist meditative and yogic practice are powerful, and often highly dramatic. But precisely because they are so dramatic, so exciting, and superficially so similar to the illusions and magic shows of theatrical performers and charlatans, ngödrup veer toward the dangerous territory of (mis)using the power of Buddhist practices to control others. Tibetan religious literature is rife with stories of powerful yogins who used their yogic abilities to harm enemies, win battles, and otherwise advance what appear to be worldly agendas. ${ }^{35}$ Such yogic interventions are troublingly ambiguous, and often seem to render the general category of ngödrup suspect.

As the Drikung scholars I spoke with and many other Tibetan sources explain, from a soteriological perspective, "ordinary" kinds of yogic powers are frequently classified as a distraction from the real goal, which is Buddhahood itself. The display of yogic powers is often criticized in Indian and Tibetan canonical sources, as when Buddha Śākyamuni criticizes or forbids attachment to or displays of such powers on the part of Buddhist monastics (Fiordalis 2010; Gethin 2011). One reason given for this is that there is said to be nothing inherently Buddhist about yogic display; practitioners of various meditation systems can expect to develop parallel abilities (and of course, skilled illusionists and other kinds of theatrical performers can often simulate some of the "special effects," so to speak). For this reason, displays of yogic power are sometimes described in Indic sources and by Tibetan exegetes as counterproductive when used to encourage people to practice Buddhism. ${ }^{36}$ The dramatic quality of ngödrup displays may only increase the skepticism of those who are already skeptics-a Buddhist yogin may simply look like all the other (potentially fraudulent) performers out there. Conversely, for credulous people, the faith that is inspired in them by ngödrup displays is likely to be of a naïve and superficial kind.

Dzuntrül, by contrast, are understood to be expressions of true insight into the nature of reality, the natural manifestation of an enlightened state. Thus, they can be truly beneficial to others. Drikung exegetes I spoke with framed dzuntrül as having a completely altruistic orientation, entirely responsive to others' needs. As Khenchen Nyima Gyaltsen explained to me, dzuntrül manifest spontaneously,

$34 R d z u$ ' $p h r u l$ can also translate the Sanskrit term pratiharya. On $r d d h i$ and some ways of classifying $r d d h i$ and related terms abhijñ $\bar{a}$ and vidy $\bar{a}$ in Indic sources, as well as on ambiguity and slippage of these terms in Sanskrit and Pali materials, see (Fiordalis 2008, 2010, 2013, 2014; Gethin 2011; Gómez 2010). Note the ambiguity of the term rdzu 'phrul in Tibetan in other contexts, where it can connote illusion or deceit (Gómez 2010); (Barstow 2013).

35 However, it should be remembered that Tibetan adepts who are criticized in some sources as misusing their yogic powers are valorized in other sources, often those composed by their disciples, as acting for profound enlightened purposes ordinary audiences cannot discern; the context of interpretation remains crucial. See for instance (Yamamoto 2012; Cuevas 2015; Sperling 2001).

36 Although see (Fiordalis 2008) for discussion of the complex role of forms of Buddhist power in conversion narratives in Indic canonical sources. 
in an interactive way, through an interpersonal encounter between an enlightened teacher and his or her disciples or potential disciples with their particular karmic predispositions and needs. ${ }^{37}$ This responsiveness sets $d z u n t r u ̈ l ~ a p a r t$ from the potentially manipulative power embodied in ngödrup.

Seen in this way, Amgön's displays of dzuntrül emerge in narratives about him as literally drawn out of him by the situations of those he encounters. He is often depicted as using his yogic abilities, especially his clairvoyance, in a highly individualized way to teach those around him, with different interventions for different kinds of people. For instance, when Amgön interacts with the powerful Reting Rinpoche, Amgön is said to deliver a cryptic speech, describing Reting as like the golden arrow on top of a flag of victory, which will one day fall off and land on the ground. For audiences in the present day (and perhaps at the time), the metaphor of the fallen golden arrow is a clear reference to Reting's coming downfall. Audiences may know that Reting not only fell from power, but ultimately died in prison, apparently assassinated. Amgön seems to be drawing on his clairvoyance to warn Reting, and he communicates his insight using a range of images (victory flags, gold, arrows) a ruler might respond to, though in this instance Reting does not seem to heed him. ${ }^{38}$

In other episodes, students do respond. Dordzin Rinpoche recounted for me a moving story of a time when Amgön Rinpoche was approached by a distraught mother, whose son had recently been born with a cleft palate (a disfiguring condition, effectively incurable in mid-twentieth century Tibet, which often drastically limited a person's marriage and other life choices). Amgön Rinpoche assured the mother that though her son was burdened by the liability of this facial disfigurement, he would in fact grow to be the best and most influential of all her children, taking solicitous care of her in her old age and restoring their family's name. The mother is described as deeply reassured (and Dordzin Rinpoche noted that in fact the son in question did grow up to be a prominent man). ${ }^{39}$ In another narrative, one recorded in the 2004 namtar, Amgön Rinpoche is shown transforming beer offered by a bon vivant disciple into pure water and then back to beer again (but beer with a special and delicious taste), thus inspiring the beer-loving disciple toward faith (Dkon mchog rgya mtsho Ra se zla ba, p. 43). In each of these examples and a host of others, Amgön's dzuntrül manifest interpersonally and address a particular disciple's individual situation. The beer-lover is drawn toward Buddhist practice and devotion to Amgön through beer, the distraught mother connects with Amgön through his insights about her child. Even the powerful Regent Reting is offered a kind of personalized clairvoyant instruction, and although the namtar text and oral accounts do not show him specifically heeding Amgön's predictions of downfall, the overall message of the narratives is that Reting does develop faith in Amgön. Across all these cases and many others, Drikung commentators particularly emphasize the responsiveness and interactive quality of Amgön's pedagogy of dzuntrül display. ${ }^{40}$

\section{Bodhisattva Pedagogy}

To consider in more depth how Amgön's performative pedagogy of yogic display intersects with Khunu Lama's pedagogical performance of renunciation, I turn now to the central Mahayana ideal of the bodhisattva, which helps to link together the forgoing themes. Tibetan exegetes and audiences describe both Khunu Lama and Amgön Rinpoche as embodying the bodhisattva ideal. Indeed, much of Khunu Lama's present-day fame comes from the fact that the current Dalai Lama and other prominent Tibetan figures speak of him publicly as being a modern-day exemplar of this ideal. ${ }^{41}$ Likewise, when explaining to me how to interpret accounts of Amgön's yogic power, Dordzin

\footnotetext{
Khenchen Nyima Gyaltsen interview 2013; discussed in greater detail in (Pitkin 2016).

Dordzin Rinpoche interview 2013; also see (Dkon mchog rgya mtsho Ra se zla ba, p. 68 and ff).

Dordzin Rinpoche interview 2013.

Dordzin Rinpoche interview 2013; Khenchen Nyima Gyaltsen interview 2013; Karma Rinchen 2014.

41 For example, (Dalai Lama 1994); Tulku Pema Wangyal interview 2005; Ven. Karma Gelek Yuthok interview 2005.
} 
Rinpoche, Khenchen Nyima Gyaltsen and Karma Rinchen each separately emphasized Amgön's identity as an individual who has actualized the bodhisattva path. ${ }^{42}$

Tibetan Buddhists at many times and places have framed their understanding of the Buddhist path around the Mahayana ideal of the compassionate, skillful bodhisattva. In prayers, devotional texts, rituals, yogic exercises and inspired poetry, Buddhists across the Himalayan region locate themselves, their own Buddhist teachers, and their teachers' teachers as practitioners on the bodhisattva path. According to classic Indian Mahayana presentations that are central for Tibetan Buddhists, bodhisattvas pursue the enlightened state of Buddhahood because of their altruistic wish to free all beings from suffering by also placing them in Buddhahood. Bodhisattvas in this sense are understood to exemplify compassionate altruism, together with meditative prowess and wisdom. In their efforts to lead other beings to Buddhahood, bodhisattvas also exemplify what we might call a liberating pedagogy, the "skillful means" (Skt. upāya; Tib. thabs) that is central to theories of teaching, conflict resolution, and interpretation across forms of Buddhism in Tibet and elsewhere.

Tibetan exegetes describe bodhisattva pedagogy as potentially taking many forms. A bodhisattva's skillful interventions might range from meeting basic material needs of suffering beings, to teaching ethics and meditation to individuals beginning the Buddhist path, to advanced yogic feats of reading others' minds, discerning the future, and skillfully engaging with troubled individuals based on these supermundane forms of knowledge. ${ }^{43}$ Bodhisattvas can thus be dazzlingly visible in their extraordinary teaching methods, which can include displays of yogic power that some observers would call miraculous. Or bodhisattvas can be humble, even potentially hidden figures, hard to observe in the midst of their ordinariness.

Since bodhisattvas' skillful repertoires of teaching techniques include acting as role models, Tibetan authors sometimes suggest that bodhisattvas may visibly enact their own practice of the Buddhist path to enlightenment specifically to show other practitioners how it is done. Biographers sometimes highlight their ordinariness, their "just like us" progress through difficult obstacles to realization, framing their struggles and achievements as an ideal to be emulated. Many narratives about the beloved eleventh century Tibetan saint Milarepa, for example, and indeed about the historical Buddha, take this form (Quintman 2013). On the other hand, other narrators within the same Tibetan Buddhist biographical framework may depict enlightened masters as enacting the Buddhist path with an emphasis on "acting," suggesting that from the perspective of the master, there is ultimately no path or achievement (paraphrasing the words of the Heart Sutra), but only the spontaneous unfolding of a realization which is already present. According to non-dualistic Mahayana ways of understanding the core Buddhist principles of interdependence and selflessness, an enlightened being's enlightenment is not in an ontological sense separate from any previous un-enlightened state. ${ }^{44}$ From this latter perspective, even the practice of the Buddhist path itself has a performative quality for an already-enlightened individual, who engages in its stages as a pedagogical display for the sake of others.

As we can see here, the term bodhisattva has a certain ambiguity. A bodhisattva can be an ordinary human being who has committed to the bodhisattva path through taking vows and is working through the stages of Buddhist practice. Or a bodhisattva may be an enlightened being who has already perfected the result of the Buddhist path. In that latter sense, the term bodhisattva can also refer to a supermundane, cosmic Buddha figure personifying an aspect of enlightenment. According to Tibetan interpretations, these cosmic figures may themselves enact human life stories and narratives of

42 Dordzin Rinpoche interview 2013; Khenchen Nyima Gyaltsen interview 2013; Karma Rinchen 2014.

43 For instance (Patrul Rinpoche/Padmakara Translation Group 1994; Shantideva 1997; Dalai Lama 1994).

44 This raises a complex set of philosophical debates, which for reasons of space I cannot explore here. See for example (Makransky 1997; Patrul Rinpoche/Padmakara Translation Group 1994; Stearns 2007; Thakchoe and Garfield 2007; Thurman 1991). 
enlightenment by incarnating as human masters. The Dalai Lamas, for instance, are understood in this way to be incarnations of the cosmic enlightened figure Avalokiteshvara, who personifies compassion.

In the case of all of these kinds of bodhisattva figures, both mundane and supermundane, Buddhist scholars in the Tibetan context analyze their teaching activities as profoundly intersubjective. ${ }^{45}$ Since bodhisattvas should be by definition altruistic (or at least committed to altruism as a goal), and therefore free of private selfish agendas, they should in theory act responsively to the needs of those they are trying to help. This quality of responsiveness increases as a bodhisattva approaches Buddhahood. Stated in more technical Buddhist philosophical terms, as an individual approaches Buddhist enlightenment, she exhausts her own karmic trajectories, and acts purely as a result of the force of her prior bodhisattva vow to benefit beings, becoming at the level of skillful means (as distinguished from wisdom) an entity of purely spontaneous and perfectly skillful responsiveness. Or to express the same idea in more emotional and psychological terms, an enlightened individual is no longer trying to get anything private for themselves out of any situation. Rather, such an individual is infinitely available to benefit others in need of teaching (even if the specific interventions of such an enlightened being may not please unenlightened people around them in the short term, who have no way to fully evaluate their actions.) If one thinks of the bodhisattva as fundamentally a teacher figure, then such a bodhisattva teacher should respond skillfully and individually to the unique needs of each of her students. And, in fact, in the Tibetan Buddhist context, individuals are always encouraged to think of their own teachers as bodhisattvas, or to be more precise, as Buddhas who have reached the culmination of the bodhisattva path.

Tibetan accounts of compassionate bodhisattvas, whether understood as human teachers or enlightened beings, are deeply influenced by these Mahayana perspectives. This is especially true for the key concepts of intention and spontaneity. If an ideal bodhisattva is infinitely skillful, in the sense of infinitely responsive to each unique disciple or potential disciple, then a quality of spontaneity would seem to be built into the bodhisattva's repertoire. On the other hand, a bodhisattva's spontaneity in meeting others' needs emerges within the context of a very powerful set of intentions, both the bodhisattva's overarching prior intention to benefit others, expressed as a vow, and her immediate intention to help the person in front of her. While from a Tibetan Buddhist point of view this is not a form of selfish intentionality, these are decisive intentions nonetheless. ${ }^{46}$

Tibetan Buddhist intellectual traditions possess a rich and detailed vocabulary for thinking about the intentionality and power of advanced Buddhist practitioners, bodhisattvas, and Buddhas. Building on earlier Indian taxonomies, Tibetan exegetes map a four-fold repertoire of enlightened activity (Tib. 'phrin las rnam bzhi) enacted by Buddhas for the benefit of others, or ritually and imaginatively engaged in by practitioners on the bodhisattva path. In this schema, the four kinds of enlightened activity are pacifying (Tib. zhi ba), enriching (Tib. rgyas pa), magnetizing or mastering (Tib. dbang $b a$ ), and destroying or wrathful (Tib. drag po). These activities include pacifying threats to human flourishing, such as conflicts and sickness; increasing positive circumstances like health, virtue and auspiciousness; charismatically and powerfully guiding people and non-human beings; and forcefully subduing those who would do harm. Perhaps it is not surprising that the authors Donald Lopez Jr and Steven Rockefeller refer to this list, somewhat provocatively, as the "four political activities" (Lopez and Rockefeller 1987).

Tibetan intellectual and popular traditions acknowledge the power of advanced practitioners with enthusiasm and awe, but also with ambivalence. Tibetan authors and commentators often ask, directly

45 Here and in what follows, I am especially guided by the exegetical approach of the already-mentioned Drikung scholar Khenchen Nyima Gyaltsen, together with the comments of another leading Drikung scholar and teacher, Khenchen Könchok Gyaltsen, based on interview conversations and personal communications in 2004 and 2013. This emphasis on responsiveness and intersubjectivity is a mainstream and standard feature of Tibetan presentations of the bodhisattva's role (Dalai Lama 1994; Pitkin 2016; Pitkin; Shantideva 1997; Thondup 1996; Patrul Rinpoche/Padmakara Translation Group 1994; Gyatso 1998). I am indebted to Holly Gayley for the term "intersubjective."

46 I am grateful to Dominique Townsend for this observation. 
or by implication, whether expressions of power can risk becoming manipulative. Might the above accounting of the four activities be used to rationalize domination, for instance if a powerful king or general is also understood as a bodhisattva? (Cuevas 2015; Mills 2012; Sperling 2001; Yamamoto 2012) Tibetan Buddhist stories about venerated masters often grapple with these anxieties, addressing in their accounts longstanding Tibetan concerns about power, manipulation, and fraud.

Ambivalence about and contestation of the mundane and supermundane powers of Buddhist leaders and advanced practitioners is a recurring theme of Tibetan religious life, from an early historical period. ${ }^{47}$ These concerns form the backdrop against which Tibetan religious virtuosi must prove themselves and establish credibility (Gyatso 1998; Gardner 2006; Stearns 2007; Jacoby 2014; DiValerio 2015; Yamamoto 2012). Tibetan Buddhist visionaries, authors and audiences from multiple historical periods give shrewd and sophisticated attention to critiquing fraud, manipulation, and exploitation, often through the use of humor and mockery. Examples are too numerous to list in full, but readers might note sharp comments about wealthy religious hierarchs who are Buddhists in name only in the life stories of Milarepa (Quintman 2013) and Tangtong Gyalpo (Stearns 2007). Janet Gyatso describes the intense pressure felt by the eighteenth century visionary Jigme Lingpa to legitimate himself as a treasure-revealer (Tib. gter ston) in a climate of suspicion (Gyatso 1998). Sarah Jacoby describes similar pressures to demonstrate authenticity and refute accusations of fraud or manipulation in the case of the twentieth century woman visionary Sera Khandro (Jacoby 2014).

Interestingly, such concerns are sometimes framed in international academic or journalistic literature as "modern," "western" or "Chinese" critiques of what is presumed to be Tibetan religious naivetè or theocratic orthodoxy. ${ }^{48}$ This is a mistake. The examples introduced above all complicate these prejudices, challenging presentations of Tibetans and Tibetan societies as naively credulous, while also challenging views of Tibet as always peaceful or nonviolent.

The English term "performance" further illuminates Tibetan concerns about Buddhist masters' powers. Performances can be spontaneous, with both performer and audience experiencing them as authentic and natural. Nevertheless, the term "performance" also carries a strong implication of intentionality, where extensive preparation and training is required. This can have negative connotations, such as implying artifice. Here the term performance can refer precisely to what is not natural, what is calculated so as to produce an effect, what is "only an act."

This disquieting polysemic semantic field is not unique to the English performance. Buddhist authors across multiple historical periods and linguistic settings have used performance-related terms as metaphors for the delusory or illusion-like qualities of our ordinary experience of ourselves and the world around us. Buddhist authors also use the vocabulary of misleading performance to describe the manipulative actions of yogins who deploy their powers or religious status deceptively, coercively, or to enrich themselves. This association of performance with fakery and with delusion or ignorance marks performance as something two-edged and potentially problematic, both in Buddhist analysis, in non-Buddhist Indic literatures, and in western scholarship. ${ }^{49}$

Tibetan and more general Buddhist concerns about artifice, illusion, delusion, and manipulation inform the context for engaging with stories about masters like Amgön Rinpoche and Khunu Lama. Stories about their bodhisattva repertoires of liberating pedagogy respond to Tibetan anxieties about the dangers of powerful intentions in the hands of powerful people. In this context, spontaneity and the idea of the bodhisattva's responsiveness to the needs of others emerge as crucial proof of authenticity. Spontaneity (rather than predetermined intention) and responsiveness to the needs of

47 See for instance the dynamics analyzed in (Dalton 2011; Gyatso 1998; Kapstein 2000); the contested accounts discussed in (Cuevas 2015; Yamamoto 2012).

48 For instance, the issues raised in (Aris 1989). (King 1999; Lopez 1998) discuss some of these dynamics; relatedly see (McMahan 2008; Gyatso 2011; Tuttle 2005). (Asad 2003; Bubandt and van Beek 2012) raise important related issues.

49 In relation to this see (Aris 1989; Pollock 2011, 2016; Shulman 2012; Strong 2007). 
students (rather than enacting one's own egocentric agenda) appear as the hallmarks of true, selfless and thus morally pure bodhisattva activity.

Considered from this point of view, one way to understand how Khunu Lama and Amgön Rinpoche are remembered is to say that Khunu Lama is shown as a practitioner of exceptional renunciation, who is personally concerned to avoid even a trace of manipulation or the dominating exercise of power over others. He is therefore shown as a hidden yogin, one whose bodhisattva pedagogy of concealment refuses all (morally and psychologically treacherous) performance or display. Amgön Rinpoche, by contrast, is remembered as ebulliently performative in his yogic displays, embracing a bodhisattva style we could call a pedagogy of the visible, even a pedagogy of the dramatic. Yet his pedagogy is also viewed as pure and moral by biographers and commentators, specifically because they interpret it as entirely spontaneous and altruistically responsive to the needs of others, rather than calculating or egocentric. This interpretation of Amgön's pedagogy of yogic display as spontaneous and altruistic is connected to Amgön's invocation of secrecy and his own intensive practices of renunciation. It is also grounded in the framing of his extraordinary activities as dzuntrül rather than ngödrup..$^{50}$

A further way to think about Khunu Lama and Amgön Rinpoche's life stories is to correlate them with two different ways of understanding bodhisattva activity: bodhisattvas performing in order to model Buddhist practices for their disciples, and bodhisattvas spontaneously displaying enlightened qualities in order to benefit their disciples. Khunu Lama's biographers have tended to emphasize his intensive practice of the bodhisattva path as an ideal to be emulated, a model to inspire others. Accounts of his life thus pay close attention to his extraordinary care in practicing renunciation and scholarship, both of which Khunu Lama is said to have raised to a virtuosic level. Both of these are forms of activity carrying some sense of effort; they are practices, rather than results, and they suggest a framework of self-cultivation.

Stories about Amgön Rinpoche, on the other hand, tend to emphasis his spontaneity, the irrepressible expression, as it were, of his enlightened relationship with reality in the intersubjective context of engaging other people. His spontaneity results in extraordinary displays that teach by showing what enlightenment looks like, and by thus inspiring genuine (as opposed to naïve) faith. While early chapters of the 2004 biography of Amgön Rinpoche do discuss the meditative practices through which he is said to have reached realization, especially his practice of the tradition called Mahamudra or Great Seal, his oral biographers and the 2004 biography highlight his later years as a teacher, when he teaches by manifesting enlightened qualities. The Tibetan scholars with whom I have discussed narratives of Amgön's life describe him as thus showing the fruits of the Buddhist path, rather than the stages of the path. ${ }^{51}$

In this sense, Amgön is seen as displaying what Buddhahood is like through his yogic performances. Amgön Rinpoche's yogic displays are not presented by the scholars I spoke with as forms of self-cultivation in the ordinary sense, although they do result from his previous meditation practice. His yogic displays are instead framed as a welling-up of his direct perception of reality, as well as of his compassion for others. That is to say, Amgön Rinpoche's yogic displays function explicitly as sources of Buddhist inspiration for audiences, rather than as detailed guides to Buddhist practice. ${ }^{52}$ Following the interpretive lead of Drikung scholars like Khenchen Nyima Gyaltsen, we might say that Amgön is shown using his yogic performances as part of a pedagogy of faith, one that inspires audiences to believe in and aspire to the results of the path for themselves. ${ }^{53}$

50 Dordzin Rinpoche interview 2013; Khenchen Nyima Gyaltsen interview 2013.

51 Dordzin Rinpoche and Khenchen Nyima Gyaltsen, interviews 2013.

52 Dordzin Rinpoche and Khenchen Nyima Gyaltsen, interviews 2013. I discuss the role of faith vis a vis Amgön's yogic displays in detail in (Pitkin 2016).

53 Khenchen Nyima Gyaltsen explicitly connects Amgön Rinpoche's yogic displays to the need and capacity of the disciples for faith. Khenchen Nyima Gyaltsen interview 2013, personal communication 2016. See also (Pitkin 2016). 


\section{Final Scene}

In 2013, I had the opportunity to talk at length with Khenchen Nyima Gyaltsen about his knowledge of both Khunu Lama and Amgön Rinpoche. At that time, he told me another version of the meeting between the two men, an oral account told to him by a close relative who had been a disciple of both. In this version of the story of their meeting, the two men make what is called in Tibetan a "religious connection" (Tib. chos "brel).

According to this oral narrative, Khunu Lama visits Amgön Rinpoche in his meditation cave. Amgön Rinpoche offers Khunu Lama the inexhaustible tea and sugar, thus delighting Khunu Lama with his realization and enlightened qualities. Then Khunu Lama asks Amgön Rinpoche if he will bestow on Khunu Lama the Buddhist transmission of an important meditation practice from the Drikung Kagyü tradition, the very tradition in which Amgön Rinpoche practices, to make a religious teacher-student connection between them. Amgön Rinpoche gets up from his seat and walks around Khunu Lama. He does not read a text or perform anything one might ordinarily identify as a ritual; he leaves undone anything that might conventionally constitute a form of religious transmission. Instead, Amgön touches Khunu Lama with his own face, cheek to cheek, forehead to forehead, nose to nose. Then he says, "That's it." 54

For ever after that, Khunu Lama is said to have told people, “Oh yes, I received that Drikung Kagyü transmission from Amgön Rinpoche-not with words, but with the meaning." 55

In this final scene, we see the multiple levels on which both men might be called renunciants, not only the parallel ways in which each is remembered as abandoning possessions, status, comfortable clothing and food, but also the way that they both are remembered as renouncing religious status and ritual, as well as renouncing ordinary unenlightened perception. I would argue that we find a special genre of pedagogical bodhisattva performance in this scene. This is a performance of renouncing all conventionality, including religious ritual conventions. It is equally a performance that also enacts, expresses, and transmits the state of enlightenment, spontaneously, in the context of an intimate human relationship.

One might further speculate that renunciation like Amgön's and Khunu Lama's in these stories acts as a protection against accusations that one is using one's power and charisma for some kind of personal gain or political project. After all, both renunciation and displays of yogic power are on some level about power-they enhance an individual's charisma, and display that charisma. And as we have already noted, the pleasure, power, efficacy and (from a Mahayana soteriological perspective) necessity of bodhisattva performances is often tempered in Tibetan narratives by the sense that ordinary worldly agendas can render bodhisattva power deeply problematic.

Indeed, that might be one way to understand the figure of Reting Rinpoche in Amgön's oral and textual biographies. His role in Amgön's biographies may be to show the potential for ordinary kinds of political power and success to go awry, even for high ranking Buddhist figures. It would be an overstatement to say Reting is a literary foil for Amgön. But the moral and narrative ambiguity with which he is presented-the prestige his visits and gifts confer, contrasted with his fallibility and the conflicts he is known to be embroiled in-highlight the complexities of exercising power in an intentional way. The ambiguity of such a figure clarifies the stakes for Tibetan audiences of framing bodhisattva power, bodhisattva pedagogy, and bodhisattva performances as spontaneous, altruistic, and free from selfish agendas. Legitimate bodhisattva pedagogy must be powerful and world shaping, yet free of manipulation. ${ }^{56}$

In this context, renunciation as a practice takes on immense moral and narrative weight. Renunciation acts as a guarantor of the genuineness of someone's altruism. Legitimation in a Tibetan

\footnotetext{
54 Khenchen Nyima Gyaltsen, interview 2013.

55 Khenchen Nyima Gyaltsen, interview 2013.

56 Of course, for Reting's own disciples and community, these events and their interpretation can be framed quite differently.
} 
Buddhist context of audience suspicion may even require certain practices or displays of renunciation, which demonstrate that one is not seeking one's own power or fame. The quality of renunciation that Amgön Rinpoche displays in the special transmission scene above, and which disciples so frequently describe Khunu Lama as displaying thus functions as a crucial mark of legitimacy. ${ }^{57}$

In narratives of Amgön Rinpoche's and Khunu Lama's lives, we see an interplay between disciplined virtuosic renunciation and dramatic virtuosic yogic display, between hidden concealment and flamboyant visibility. Renunciation and yogic display are not separate in these two Tibetan Buddhist exemplifications of bodhisattva activity. Hiding and making visible are not opposing pedagogical strategies, but are rather two complementary aspects of a continuous emancipatory performance, one that is both meticulously cultivated and responsively spontaneous, disciplined and free, concealed and dazzling.

Acknowledgments: This research received generous support from the Social Science Research Council, the Fulbright-Hays Foundation, and a Blakemore-Freeman Fellowship. I thank Kalsang Wangdu for his insightful research assistance. I am grateful to the Drikung Kagyü scholars who shared their expertise with me, especially H.H. Kyabgon Chetsang Rinpoche, Khenchen Könchok Gyaltsen, Dordzin Rinpoche, Khenchen Nyima Gyaltsen, Karma Namgyal, and the Director and staff of the Drikung Kagyü Institute in Dehradun, India. I am indebted to the many students of Khunu Lama Tenzin Gyaltsen who shared their recollections with me. In particular, I am grateful to Khunu Lama's main Tibetan-language biographers, the late K. Angrup, the late Khetsun Sangpo Rinpoche, and Drikung Lamchen Gyalpo Rinpoche, and to western-language scholars of Khunu Lama's life and related topics, especially Gareth Sparham, Jurgen Manshardt, Thierry Dodin, Linda LaMacchia, and David Jackson. These scholars exemplify the virtues of scholarship and generosity Khunu Lama himself was said to prize. I am particularly indebted to Tashi Tsering of the Amnye Machen Institute, whose extraordinary erudition and support made the research presented here possible. All errors are my own.

Conflicts of Interest: The author declares no conflict of interest.

\section{Appendix A. Interviews Cited}

Karma Rinchen, 2014, New York City

Dordzin Drupon Dondrup Palden Rinpoche, 2013, Dehradun, India

Khenchen Nyima Gyaltsen, 2013, Dehradun, India

Chokyi Nyima Rinpoche, 2010, Garrison, New York

Rakra Tethong Rinpoche, 2006, Switzerland

Khenpo Sonam Topgyal, 2006, New York City

Trulku Pema Wangyal, 2005, Dharamsala, India

Ven. Karma Gelek Yuthok, 2005, Dharamsala, India

Khenchen Könchok Gyaltsen, 2004, Dehradun, India

Mrs. Namgyel Taklha, 2004, Dehradun, India

K. Angrup, 2004, Keylong, Lahaul, India

Tashi Rabgias, 2004, Leh, Ladakh

Geshe Yeshe Tapgyes, 2004, Sarnath, India

Sem Trinley Ongmo, 2004, Sikkim, India

Drukpa Trulku, 2006, Bodhnath, Nepal; interviewed by David Jackson. Interview shared by David Jackson, personal communication.

\section{References}

Angrup, K. 1989. Khu Nu Rin Po Che'i Rnam Thar Thar Pa'i Them Skas Zhes bya ba Bzhugs So. Sarnath: Central Institute of Higher Tibetan Studies.

Angrup, K. 2005. Khu nu Rin Po Che bla ma Bstan 'Dzin Rgyal Mtshan Dpal Bzang Po'i Mdzad Rnam Thar Pa'i Them Skas. Sarnath: Central Institute of Higher Tibetan Studies.

57 There are interesting parallels with the dynamics of legitimation, doubt, and reassurance described by Jacoby in the life of Sera Khandro (Jacoby 2014). 
Ardussi, John, and Lawrence Epstein. 1975. The Saintly Madman in Tibet. Thousand Oaks: SAGE Publications.

Aris, Michael. 1989. Hidden Treasures and Secret Lives: A Study of Pemalingpa (1450-1521) and the Sixth Dalai Lama (1683-1706). London: Kegan Paul International.

Asad, Talal. 2003. Formations of the Secular: Christianity, Islam, Modernity. Stanford: Stanford University Press.

Barstow, Geoffrey. 2013. Buddhism between Abstinence and Indulgence: Vegetarianism in the Life and Works of Jigmé Lingpa. Journal of Buddhist Ethics 20: 74.

'Bri gung pa chos 'byor. 1996. 'Bri Gung Mtshams pa Grub thob a Mgon Rin po Che'i Namthar. Oral History Series no. 1; Dharamsala: Library of Tibetan Works and Archives.

Nils Bubandt, and Martin van Beek, eds. 2012. Varieties of Secularism in Asia: Anthropological Explorations of Religion, Politics and the Spiritual. New York: Routledge/Taylor and Francis Group.

Butler, Judith. 1988. Performative Acts and Gender Constitution: An Essay in Phenomenology and Feminist Theory. Theatre Journal 40: 519-31. [CrossRef]

Clarke, Shayne. 2013. Family Matters in Indian Buddhist Monasticisms. Honolulu: University of Hawai'i Press.

Clough, Bradley S. 2010. The Higher Knowledges in the Pāli Nikāyas and Vinaya. Journal of the International Association of Buddhist Studies 33: 409-33.

Cuevas, Bryan. 2015. The All-Pervading Melodious Drumbeat: The Life of Ra Lotsawa. New York: Penguin Classics.

Dalai Lama, Tenzin Gyatso. 1994. A Flash of Lightening in the Dark of Night: A Guide to the Bodhisattva's Way of Life. Boston: Shambhala Dragon Editions.

Dalton, Jacob. 2011. The Taming of the Demons: Violence and Liberation in Tibetan Buddhism. New Haven: Yale University Press.

DiValerio, David. 2015. The Holy Madmen of Tibet. Oxford: Oxford University Press.

Dkon mchog rgya mtsho (Ra se zla ba). 2004a. Grub pa'i dbang phyug chen po a mgon rdo rje 'chang gi rnam thar rags bsdus bka' brgyud bstan pa'i mdzes rgyan. Lhasa: Bod ljongs mi dmangs dpe skrun khang.

Dkon mchog rgya mtsho (Ra se zla ba). 2004b. 'Bri gung chos 'byung. Beijing: Mi rigs dpe skrun khang.

Dodin, Thierry. 1997. Negi Lama Tenzin Gyaltsen: a preliminary account of a modern Buddhist Saint. In Recent Research on Ladakh 6: Proceedings of the Sixth International Coloquium on Ladakh, Leh 1993. Edited by Osmaston and Tsering. Delhi: Motilal Banarsidas.

Dung dkar blo bzang 'phrin las. 2002. Dung dkar tshig mdzod chen mo. Beijing: Krung Go'i Bod Rig Pa Dpe Skrun Khang.

Fiordalis, David. 2008. Miracles and Superhuman Powers in South Asian Buddhist Literature. Ph.D. dissertation, University of Michigan, Ann Arbor, MI, USA.

Fiordalis, David. 2010. Miracles and superhuman powers in South and Southeast Asian Buddhist traditions. Journal of the International Association of Buddhist Studies 33: 1-2.

Fiordalis, David. 2013. Abhijñā/Ṛddhi (Extraordinary Knowledge and Powers). In Oxford Bibliographies Online. Oxford: Oxford University Press.

Fiordalis, David. 2014. Buddhist Miracles. In Oxford Bibliographies Online. Oxford: Oxford University Press.

Gardner, Alexander. 2006. The twenty-five great sites of Khams: Religious geography, revelation, and nonsectarianism in nineteenth-century eastern Tibet. Ph.D. dissertation, University of Michigan, Ann Arbor, MI, USA.

Gethin, Rupert. 2011. Tales of Miraculous Teachings: Miracles in Early Indian Buddhism. In The Cambridge Companion to Miracles. Edited by Graham H. Twelftree. Cambridge: Cambridge University Press, pp. 216-34.

Gómez, Luis O. 2010. On Buddhist Wonders and Wonderworking. Journal of the International Association of Buddhist Studies 33: 513-54.

Gruber, Elmar. R. 2010. From the Heart of Tibet: The Biography of Driking Chetsang Rinpoche, the Holder of the Drikung Kagyu Lineage. Boston: Shambhala Publications.

Gyatso, Janet. 1998. Apparitions of the Self: The Secret Autobiographies of a Tibetan Visionary. Princeton: Princeton University Press.

Gyatso, Janet. 2011. Introduction. In Mapping the Modern in Tibet. Edited by Gray Tuttle. Andiast: International Institute for Tibetan and Buddhist Studies GmbH, pp. 1-44.

Jacoby, Sarah. 2014. Love and Liberation: Autobiographical Writings of the Tibetan Buddhist Visionary Sera Khandro. New York: Columbia University Press.

Sarah Jacoby, and Antonio Terrone, eds. 2009. Buddhism beyond the Monastery: Tantric Practices and Their Performers in Tibet and the Himalayas. Leiden: Brill's Tibetan Library. 
Kapstein, Matthew. 1998. A Pilgrimage of Rebirth Reborn: The 1992 Celebration of the Drigung Powa Chenmo. In Buddhism in Contemporary Tibet: Religious Revival and Cultural Identity. Edited by Melvyn Goldstein and Matthew Kapstein. Berkeley: University of California Press, pp. 95-119.

Kapstein, Matthew. 2000. The Tibetan Assimilation of Buddhism: Conversion, Contestation and Memory. Oxford: Oxford University Press.

Khetsun Sangpo Rinpoche. n.d. Khu nu bla ma Rin po Che'i Rnam par Thar pa Nyid Kyi Zhal Gsungs Ma.

King, Richard. 1999. Orientalism and Religion: Post-colonial theory, India and the Mystic East. New York: Routledge. LaMacchia, Linda. 2008. Songs and Lives of the Jomo: (Nuns) of Kinnaur, Northwest India: Women's Religious Expressions in Tibetan Buddhism. Delhi: Sri Satguru Publications.

Lamchen Gyalpo, Rinpoche. 2011. Sunlight Blessings that Cure the Longing of Remembrance: A Biography of the Omniscient Khunu Mahasattva. Translated by Erick Tsiknopoulos and Mike Dickman. Available online: https:/ / buddha-nature.com/2011/10/15/sunlight-blessings-that-cure-the-longing-of-remembrance-abiography-of-the-omniscient-khunu-mahasattva-tenzin-gyeltsen-khunu-lama-rinpoche-by-lamchengyalpo-rinpoche/ (accessed on 27 August 2017).

Larsson, Stefan. 2012. Crazy for Wisdom: The Making of a Mad Yogin in Fifteenth Century Tibet. Leiden: Brill's Tibetan Studies Library.

Lopez, Donald S., Jr. 1998. Prisoners of Shangri-La: Tibetan Buddhism and the West. Chicago: University of Chicago Press.

Lopez, Donald S., Jr., and Steven Rockefeller. 1987. The Christ and the Bodhisattva. Suny Series in Buddhist Studies; Albany: Suny Press.

Makransky, John. 1997. Buddhahood Embodied: Sources of Controversy in India and Tibet. Albany: SUNY Press.

Manshardt, Jurgen. 2004. Allen Freund sein: Poesie des Erleuchtungsgeistes. München: Diamant Verlag.

Manshardt, Jurgen. 2008. Die Yogini aus der Geheimen Hohle: Das Leben Der Tibetischen Yogini Drikung Khandro. München: Otter Verlag.

McMahan, David L. 2008. The Making of Buddhist Modernism. New York: Oxford University Press.

Mills, Martin. 2000. Vajra-brother, Vajra-Sister: Renunciation, Individualism and the Household in Tibetan Buddhist Monasticism. Journal of the Royal Anthropological Institute 6: 17-34. [CrossRef]

Mills, Martin. 2012. Ritual as History in Tibetan Divine Kingship: Notes on the Myth of the Khotanese Monks. History of Religions 51: 219-20. [CrossRef]

Patrul Rinpoche/Padmakara Translation Group. 1994. Words of My Perfect Teacher. Boston: Shambhala Publications.

Pitkin, Annabella. 2009. Like pouring water into water: Buddhist lineages, modernity and the continuity of memory in the twentieth -century history of Tibetan Buddhism. Ph.D. dissertation, Columbia University, New York, NY, USA.

Pitkin, Annabella. 2011. Lineage, Authority and Innovation: The Biography of Khunu Lama Tenzin Gyaltsen. In Mapping the Modern in Tibet. Edited by Gray Tuttle. Andiast: International Institute for Tibetan and Buddhist Studies GmbH, pp. 173-204.

Pitkin, Annabella. 2016. The 'Age of Faith' and the 'Age of Knowledge': Secularism and Modern Tibetan Accounts of Yogic Power. Himalaya: The Journal of the Association for Nepal and Himalayan Studies 36: 96-115.

Pitkin, Annabella. Forthcoming. Beggar Modern: Renunciation, Longing and Love in the Life of a Twentieth Century Tibetan Buddhist Saint. Book manuscript in process. Unpublished manuscript.

Pollock, Sheldon. 2011. Forms of Knowledge in Early Modern Asia: Explorations in the Intellectual History of India and Tibet, 1500-1800. Durham: Duke University Press.

Pollock, Sheldon. 2016. A Rasa Reader: Classical Indian Aesthetics. New York: Columbia University Press.

Pranke, Patrick. 2010. On Saints and Wizards: Ideals of Human Perfection and Power in Contemporary Burmese Buddhism. Journal of the International Association of Buddhist Studies 33: 453-88.

Quintman, Andrew. 2013. The Yogin and the Madman: Reading the Biographical Corpus of Tibet's Great Saint Milarepa. New York: Columbia University Press.

Scheible, Kristin. 2010. Priming the Lamp of Dhamma - The Buddha's Miracles in the Pāli Mahāvamsa. Journal of the International Association of Buddhist Studies 33: 453-51.

Schopen, Gregory. 1997. Bones, Stones, and Buddhist Monks: Collected Papers on the Archeology, Epigraphy, and Texts of Monastic Buddhism in India. Honolulu: University of Hawai'i Press. 
Shantideva, Acharya. 1997. Guide to the Bodhisattva's Way of Life. Translated by Vesna Wallace, and Alan Wallace. Boston: Shambala.

Shulman, David. 2012. More Than Real: A History of the Imagination in South India. Cambridge: Harvard University Press.

Sihlé, Nicolas. 2013. Rituels Bouddhiques de Pouvoir et de Violence: La Figure du Tantriste Tibétain [Buddhist Rituals of Power and Violence: The Figure of the Tibetan Tantrist]. Bibliothèque de l'École des Hautes Études-Sciences religieuses 152; Turnhout: Brepols.

Sparham, Gareth. 1999. Vast as the Heavens Deep as the Sea: Verses in Praise of Bodhicitta. Boston: Wisdom.

Sperling, Elliot. 2001. Aspects of Violence in the Tibetan Tradition. In Imagining Tibet-Perceptions, Projections, and Fantasies. Edited by Thierry Dodin and Heinz Raether. Boston: Wisdom Publications, pp. 317-29.

Stearns, Cyrus. 2007. King of the Empty Plain: The Tibetan Iron-Bridge Builder Tangtong Gyalpo. Ithaca: Snow Lion Press.

Strong, John. 2007. Relics of the Buddha. Princeton: Princeton University Press.

Thakchoe, Sonam, and Jay Garfield. 2007. The Two Truths Debate: Tsongkhapa and Gorampa on the Middle Way. Boston: Wisdom Publications.

Thondup, Tulku. 1996. Masters of Meditation and Miracles: Lives of the Great Buddhist Masters of India and Tibet. Boston: Shambhala.

Thurman, Robert. 1991. The Central Philosophy of Tibet: A Study and Translation of Jey Tsong Khapa's Essence of True Eloquence. Princeton: Princeton University Press.

Tuttle, Gray. 2005. Tibetan Buddhists in the Making of Modern China. New York: Columbia University Press. Willis, Jan. 1995. Enlightened Beings: Life Stories from the Ganden Oral Tradition. Boston: Wisdom Publications. Yamamoto, Carl. 2012. Vision and Violence: Lama Zhang and the Politics of Charisma in Twelfth-Century Tibet. Leiden: Brill.

(C) 2017 by the author. Licensee MDPI, Basel, Switzerland. This article is an open access article distributed under the terms and conditions of the Creative Commons Attribution (CC BY) license (http:/ / creativecommons.org/licenses/by/4.0/). 